\title{
Spirochaeta americana sp. nov., a new haloalkaliphilic, obligately anaerobic spirochaete isolated from soda Mono Lake in California
}

\author{
Correspondence \\ Richard B. Hoover \\ Richard.B.Hoover@NASA.GOV \\ Elena V. Pikuta \\ Elena.Pikuta@msfc.nasa.gov
}

\author{
Richard B. Hoover, ${ }^{1}$ Elena V. Pikuta, ${ }^{1}$ Asim K. Bej, ${ }^{2}$ Damien Marsic, ${ }^{3}$ \\ William B. Whitman, ${ }^{4}$ Jane $\mathrm{Tang}^{5}$ and Paul $\mathrm{Krader}^{5}$ \\ 'NASA/NSSTC, SD-50, 320 Sparkman Dr., Huntsville, AL 35805, USA \\ 2Department of Biology, University of Alabama at Birmingham, Birmingham, AL 35294, USA \\ ${ }^{3}$ Laboratory for Structural Biology, The University of Alabama in Huntsville, MSB, Huntsville, \\ AL 35899, USA \\ ${ }^{4}$ Department of Microbiology, University of Georgia, Athens, GA 30602-2605, USA \\ ${ }^{5}$ American Type Culture Collection, 10801 University Blvd, Manassas, VA 20110, USA
}

A novel, obligately anaerobic, mesophilic, haloalkaliphilic spirochaete, strain $A S p G 1^{\top}$, was isolated from sediments of the alkaline, hypersaline Mono Lake in California, USA. Cells of the Gramnegative strain were motile and spirochaete-shaped with sizes of $0 \cdot 2-0 \cdot 22 \times 8-18 \mu \mathrm{m}$. Growth of the strain was observed between 10 and $44^{\circ} \mathrm{C}$ (optimum $37^{\circ} \mathrm{C}$ ), in $2-12 \%(\mathrm{w} / \mathrm{v}) \mathrm{NaCl}$ (optimum $3 \% \mathrm{NaCl}$ ) and between $\mathrm{pH} 8$ and 10.5 (optimum $\mathrm{pH} 9 \cdot 5$ ). The novel strain was strictly alkaliphilic, required high concentrations of carbonates in the medium and was capable of utilizing D-glucose, fructose, maltose, sucrose, starch and D-mannitol. End products of glucose fermentation were $\mathrm{H}_{2}$, acetate, ethanol and formate. Strain $\mathrm{ASpG} 1^{\top}$ was resistant to kanamycin and rifampicin, but sensitive to gentamicin, tetracycline and chloramphenicol. The $G+C$ content of its DNA was $58.5 \mathrm{~mol} \%$. DNA-DNA hybridization analysis of strain $A S p G 1^{\top}$ with its most closely related species, Spirochaeta alkalica Z-7491 ${ }^{\top}$, revealed a hybridization value of only $48 \cdot 7 \%$. On the basis of its physiological and molecular properties, strain $\mathrm{ASpG} 1^{\top}$ appears to represent a novel species of the genus Spirochaeta, for which the name Spirochaeta americana is proposed (type strain ASpG $^{\top}=$ ATCC BAA $^{\top} 392^{\top}=$ DSM $14872^{\top}$ ).
The genus Spirochaeta contains a group of free-living, saccharolytic, obligately or facultatively anaerobic, helixshaped bacteria (Canale-Parola, 1977, 1984). Analysis of $16 \mathrm{~S}$ rRNA gene sequences has shown that the spirochaetes represent a monophyletic phylum within the Bacteria (Paster et al., 1991). At the time of writing, the genus Spirochaeta contained 13 species of bacteria. These organisms occur in a wide variety of freshwater and marine environments (Canale-Parola, 1992), such as aquatic habitats (Spirochaeta aurantia) (Breznak \& Canale-Parola, 1975), freshwater mud (Spirochaeta zuelzerae, Spirochaeta stenostrepta) (Canale-Parola, 1980), marine mud (Spirochaeta isovalerica, Spirochaeta litoralis) (Hespell \& Canale-Parola, 1970; Harwood \& Canale-Parola, 1983), oilfields (Spirochaeta smaragdinae) (Magot et al., 1997) and microbial mats (Teal et al., 1996). Some members of the genus Spirochaeta are

Published online ahead of print on 8 November 2002 as DOI 10.1099/ ijs.0.02535-0.

The GenBank accession number for the 16S rDNA sequence of Spirochaeta americana ASpG $1^{\top}$ is AF373921. microbial extremophiles that inhabit environments with extremes of salinity, alkalinity, pressure and/or temperature. The spirochaete extremophiles may harbour important enzymes and proteins and, consequently, are of particular interest to biotechnologists (Bermudes et al., 1987; Barth et al., 1991; Munson et al., 1993).

Prior studies have shown that some species of the genus Spirochaeta are naturally resistant to sulfide concentrations at levels that inhibit the growth of many other microorganisms. The mesophilic halophile Spirochaeta halophila was isolated from black mud (smelling strongly of $\mathrm{H}_{2} \mathrm{~S}$ ) of Solar Lake, a high-salinity pond on the Sinai shore of the Gulf of Aqaba (Greenberg \& Canale-Parola, 1976). The obligate anaerobe strain GS-2 is a mesophilic barophile that was isolated from sulfide-rich mud samples collected at a depth of $2550 \mathrm{~m}$ near deep-sea hydrothermal vents at the Galapagos Rift ocean-floor spreading centre (Harwood et al., 1982). 'Spirochaeta bajacaliforniensis' (Fracek \& Stolz, $1985)$ is another anaerobic marine spirochaete that was isolated from a microbial mat community in sulfide-rich 
mud at Laguna Figueroa, Baja California. It was suggested that this might be a strain of $S$. litoralis, since it had almost identical physiological characteristics and a similar DNA $\mathrm{G}+\mathrm{C}$ content to $S$. litoralis (Canale-Parola, 1992). However, $16 S$ rRNA gene sequence data indicate that ' $S$. bajacaliforniensis' and S. litoralis do not represent the same species, as a pairwise comparison shows only $83.8 \%$ similarity between the two species (data from this study).

Other spirochaete extremophiles include anaerobic, thermophilic spirochaetes from hot springs in New Zealand (Patel et al., 1985), moderately thermophilic Spirochaeta caldaria from cyanobacterial mats of freshwater hot springs in Oregon and Utah (Pohlschroeder et al., 1994), and extremly thermophilic Spirochaeta thermophila from a marine littoral hydrotherm of Shiaskotan Island, Russia (Aksenova et al., 1992).

The first alkaliphilic spirochaetes (Spirochaeta alkalica, Spirochaeta africana, Spirochaeta asiatica) were isolated from brine sediments under crusts of Trona $\left[\mathrm{Na}_{3}\left(\mathrm{CO}_{3}\right)\right.$ $\left.\left(\mathrm{HCO}_{3}\right) \cdot 2\left(\mathrm{H}_{2} \mathrm{O}\right)\right]$ in the alkaline equatorial Lake Magadi in Kenya (Africa) and from sulfide-saturated mud sediments of alkaline Lake Khatyn in Tuva, Siberia (Central Asia) (Zhilina et al., 1996). In this report, we describe a novel, haloalkaliphilic, obligately anaerobic, mesophilic spirochaete isolated from a soda lake in California, USA.

Strain ASpG1 ${ }^{\mathrm{T}}$ was isolated from a black mud sample (with a strong odour of $\mathrm{H}_{2} \mathrm{~S}$ ) collected on 15 August 2000 from soda Mono Lake of northern California, USA. The mud sample was collected anaerobically under shallow water (temperature, $21 \cdot 6 \pm 0 \cdot 1{ }^{\circ} \mathrm{C}$; salinity, $7 \%$; $\mathrm{pH} 9 \cdot 9 \pm 0 \cdot 02$ ) near the south shore of Mono Lake. To obtain the enrichment culture, $0.5 \mathrm{~g}$ of wet sediment material was injected into standard Hungate tubes containing a glucose medium and incubated at $35^{\circ} \mathrm{C}$ for $3-4$ days. Phase-contrast microscopy of the enrichment cultures indicated good growth of motile, spirochaete-shaped cells. Pure cultures were obtained by serially diluting the enrichment cultures in a fresh medium and filtering $1 \mathrm{ml}$ of these cultures (from 7 dilutions) through a $0.4 \mu \mathrm{m}$ sterile membrane syringe filter (Gelman Laboratory) into medium containing D-mannitol, as described previously (Canale-Parola, 1992). Three strains of spirochaetes that exhibited indistinguishable morphological, metabolic and physiological characteristics were isolated; strain $\mathrm{ASpG} 1^{\mathrm{T}}$ was selected for further characterization. The culture of strain $\mathrm{ASpG1}^{\mathrm{T}}$ was judged to be pure because only a single type of colony morphology was observed on the agar surface after growth of the organism, and only one cell type was observed upon microscopic examination during growth of the strain on a variety of substrates.

Strain $A S p G 1^{\mathrm{T}}$ was grown in a medium modified from Zhilina et al. (1996). The medium contained $\left(\mathrm{l}^{-1}\right) 30 \mathrm{~g}$ $\mathrm{NaCl}, 2 \cdot 76 \mathrm{~g} \mathrm{Na}_{2} \mathrm{CO}_{3}, 24 \cdot 0 \mathrm{~g} \mathrm{NaHCO}_{3}, 0 \cdot 2 \mathrm{~g} \mathrm{KCl}, 0 \cdot 2 \mathrm{~g}$ $\mathrm{K}_{2} \mathrm{HPO}_{4}, 0 \cdot 1 \mathrm{~g} \mathrm{MgCl}_{2} \cdot 6 \mathrm{H}_{2} \mathrm{O}, 1 \cdot 0 \mathrm{~g} \mathrm{NH}_{4} \mathrm{Cl}, 0 \cdot 4 \mathrm{~g} \mathrm{Na}_{2} \mathrm{~S} .9 \mathrm{H}_{2} \mathrm{O}$, $0.001 \mathrm{~g}$ resazurin, $0.5 \mathrm{~g}$ yeast extract, $5 \cdot 0 \mathrm{~g}$ D-glucose, $2 \mathrm{ml}$ vitamin solution (Wolin et al., 1963) and $1 \mathrm{ml}$ trace mineral solution (Whitman et al., 1982). The final $\mathrm{pH}$ was adjusted to $9 \cdot 5$. High-purity nitrogen was used for the gas phase. Growth was observed by phase-contrast microscopy and by measurements of optical density at $595 \mathrm{~nm}$ using a spectrophotometer (Genesis 5, Spectronic Instruments).

The morphology and size range of cells of strain ASpG1 ${ }^{\mathrm{T}}$ were determined by phase-contrast microscopy, fluorescent microscopy and field emission scanning electron microscopy. Cells of strain $\mathrm{ASpG1}^{\mathrm{T}}$ were $0 \cdot 20-0 \cdot 22 \mu \mathrm{m}$ in diameter, $8-18 \mu \mathrm{m}$ in length and had regular-shaped spirals (Fig. 1a). They also stained Gram-negative. In the final stage of exponential growth, living cells, spherical bodies (sphaeroplasts) and conglomerates of dead cells of strain $A S p G 1^{\mathrm{T}}$ were imaged using a Leitz Diaplan Epifluorescent microscope and the BacLight (Molecular Probes) live versus dead fluorescent stain (Fig. 1b). Cells of strain $A S p G 1^{T}$ were highly motile and exhibited a rotating undulatory movement typical of spirochaetes. Hitachi S-4000 field emission scanning electron microscope images of strain $\mathrm{ASpG}^{\mathrm{T}}$ cells that had been destroyed by osmotic shock showed a flagellum released from the periplasmic space (Fig. 1c).

Growth of strain $A S p G 1^{\mathrm{T}}$ was observed after 3-4 days incubation on agar medium using the 'roll-tube' method (Hungate, 1969). Confluent growth was observed, and the mass was white with veil-like, irregular formations, which were a result of migration of the bacteria through the agar gel. Individual colonies were observed when strain $\mathrm{ASpG1}{ }^{\mathrm{T}}$ was grown on an agar medium containing $10 \mu \mathrm{g}$ rifampicin $\mathrm{ml}^{-1}$. These colonies were white and round with smooth, regular edges $(0 \cdot 5-2 \cdot 0 \mathrm{~mm}$ in diameter). Individual colonies were densely granulated at their centres, with the granulation diminishing towards the perimeter of the colonies (1-5 dilutions). In deep agar (6-8 dilutions), colonies of strain $\mathrm{ASpG1} 1^{\mathrm{T}}$ were 'cotton-ball-like', with an irregular spherical shape and a higher density toward their centres.

Strain ASpG1 $1^{\mathrm{T}}$ grew between 10 and $44^{\circ} \mathrm{C}$, with optimum growth at $37^{\circ} \mathrm{C}$; no growth was observed at 5 or $48^{\circ} \mathrm{C}$. Growth of the strain at $37^{\circ} \mathrm{C}$ occurred between $\mathrm{pH} 7 \cdot 8$ and $10 \cdot 5$; no growth was detected at $\mathrm{pH} 7 \cdot 0$ or $11 \cdot 0$. Strain $A S p G 1^{\mathrm{T}}$ required $\mathrm{NaCl}$ for growth, but no growth was observed in $1 \%(\mathrm{w} / \mathrm{v})$ or $15 \%(\mathrm{w} / \mathrm{v}) \mathrm{NaCl}$; the optimum concentration of $\mathrm{NaCl}$ for growth was $3 \%(\mathrm{w} / \mathrm{v})$, and the range over which growth was observed was $2-12 \%(\mathrm{w} / \mathrm{v})$ $\mathrm{NaCl}$. The novel isolate required sodium ions for growth and did not grow on a medium with $\mathrm{K}_{2} \mathrm{CO}_{3}$ instead of $\mathrm{Na}_{2} \mathrm{CO}_{3}$. Similarly, when the carbonate buffer was replaced with serine, cells of strain ASpG1 ${ }^{\mathrm{T}}$ did not grow. Thus, carbonate ions were also required for growth. Growth of strain $\mathrm{ASpG1} 1^{\mathrm{T}}$ was not dependent on chloride ions. Growth of the strain was observed after three sequential transfers in a medium in which the chloride salts were replaced with sulfate salts, but the cells became straight and lost their motility. The doubling time of the organism at optimal conditions $\left[37^{\circ} \mathrm{C}, 3 \%(\mathrm{w} / \mathrm{v}) \mathrm{NaCl}, \mathrm{pH} 9 \cdot 5\right]$ was $5 \mathrm{~h}$. 


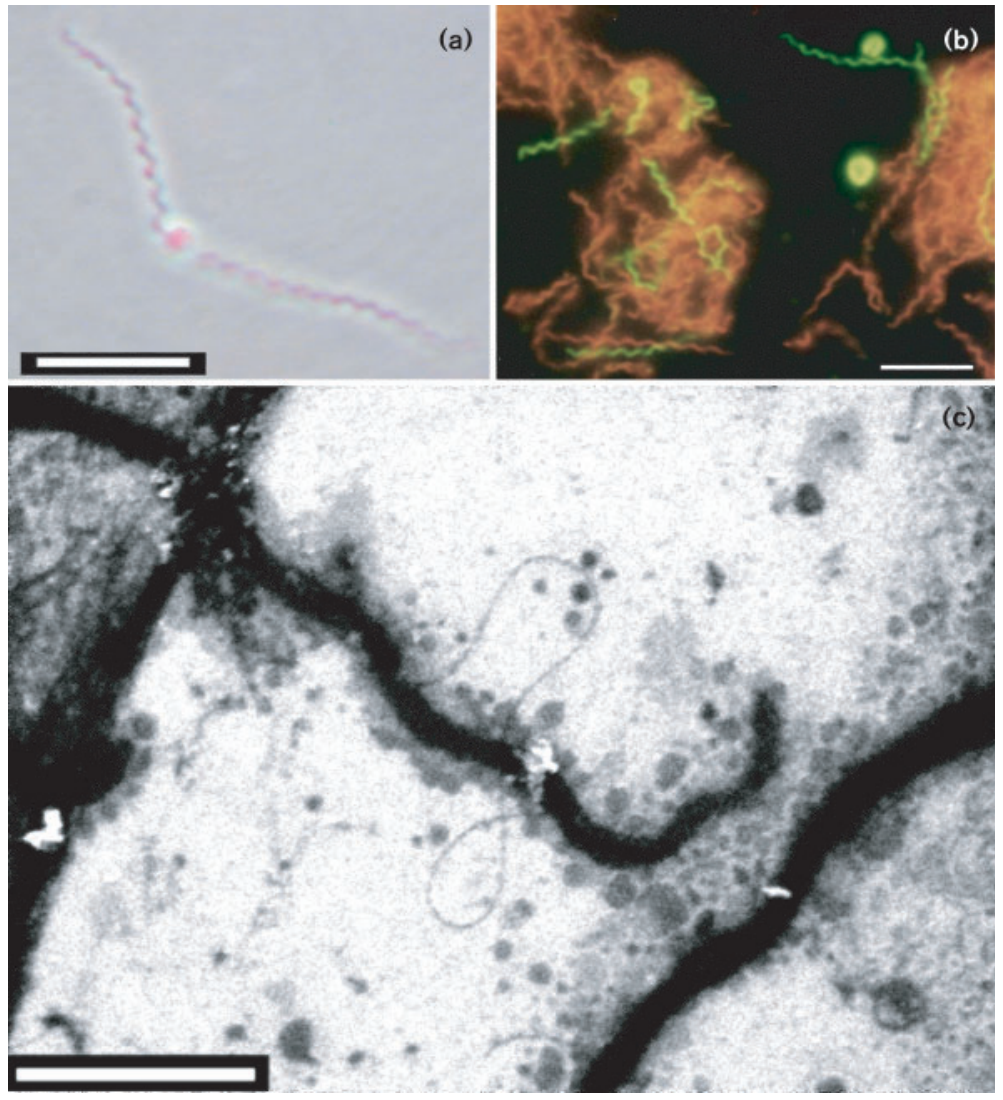

Fig. 1. Morphology of Spirochaeta americana $\mathrm{ASpG}_{1}{ }^{\top}$. (a) Phase-contrast image of a cell with a sphaeroplast in the centre. Bar, $10 \mu \mathrm{m}$. (b) BacLight live versus dead fluorescent stain of $S$. americana $A S p G 1^{\top}$ culture incubated for 3 days with rifampicin $\left(250 \mu \mathrm{g} \mathrm{m}^{-1}\right)$ showing conglomerates of dead cells (red), living cells (green) and spherical bodies (sphaeroplasts). Bar, $10 \mu \mathrm{m}$. (c) Field emission scanning electron microscope image of a cell with its membrane destroyed by osmotic shock to show flagellum released from the periplasmic space. Bar, $2 \mu \mathrm{m}$.

The novel isolate was catalase-negative (method of Gerhardt et al., 1981) and only grew under strictly anaerobic conditions. It had a fermentative type of metabolism and was an obligate chemoheterotroph. Growth of strain $\mathrm{ASpG} 1^{\mathrm{T}}$ on organic substrates was determined in the presence of $0.2 \mathrm{~g}$ yeast extract $1^{-1}$, as no growth of the organism was observed in the absence of yeast extract. Strain $A S p G 1^{T}$ grew on D-glucose, fructose, maltose, sucrose and D-mannitol. No growth was observed with acetate, lactate, pyruvate, propionate, butyrate, citrate, formate, methanol, ethanol, glycerin, peptone, yeast extract, Casamino acids, betaine or trimethylamine. Although yeast extract was required for growth of strain $A S p G 1^{T}$, it could not support growth when used as the sole substrate. The end products of fermentation in liquid phase were determined by HPLC. Separation was done on an Aminex HPX-87H (Bio-Rad) column with $5 \mathrm{mM} \mathrm{H}_{2} \mathrm{SO}_{4}$ as the mobile phase. Gases were measured using a gas chromatograph 3700 (Varian) equipped with a Porapak Q column and a TCD detector (nitrogen was the carrier gas). During growth of strain $A S p G 1^{\mathrm{T}}$ on glucose, $\mathrm{H}_{2}$ was the main end product of fermentation, and formate, acetate and ethanol were minor end products. $\mathrm{CO}_{2}$ production could not be measured due to the high carbonate level in the medium. The susceptibility of strain $\mathrm{ASpG} 1^{\mathrm{T}}$ to kanamycin, gentamicin, tetracycline, rifampicin (all at $250 \mu \mathrm{g} \mathrm{ml}^{-1}$ ) and chloramphenicol $\left(125 \mu \mathrm{g} \mathrm{ml}^{-1}\right)$ was tested. Strain ASpG1 ${ }^{\mathrm{T}}$ was resistant to kanamycin and rifampicin, but sensitive to gentamicin, tetracycline and chloramphenicol.
Fatty acid methyl esters (FAMEs) were extracted from fresh biomass and identified following the procedure recommended for the Microbial Identification System (MIDI, Sherlock Microbial Identification System Version 4.0, MIS Operating Manual March 2001). Cells of strain ASpG1 ${ }^{\mathrm{T}}$ were harvested from a broth culture grown in the modified medium described above and incubated at $37^{\circ} \mathrm{C}$ for 48 h. Extract preparation included sonication, methylation, organic extraction (transferring FAMEs from an aqueous to an organic phase) and a base wash. Then, the cell extracts were subjected to GC analysis (MIDI). The major FAMEs of strain ASpG $1^{\mathrm{T}}$ were $\mathrm{C}_{14: 0}(11 \cdot 94 \%), \mathrm{C}_{16: 0}(14 \cdot 42 \%)$, dimethyl acetate $\mathrm{C}_{16: 0}(12.55 \%), \mathrm{C}_{18: 1}(9 \cdot 75 \%)$ and a mixture of $\mathrm{C}_{18}$ unsaturated fatty acids in both the cis and trans configurations $(31 \cdot 58 \%)$. Aldehydes were present in lower amounts: $\mathrm{C}_{16: 0}(4 \cdot 69 \%), \mathrm{C}_{16: 1}(5 \cdot 79 \%), \mathrm{C}_{18: 0}$ $(5 \cdot 21 \%)$ and $\mathrm{C}_{20: 1}(2 \cdot 63 \%)$.

The $\mathrm{G}+\mathrm{C}$ content of the genomic DNA of strain ASpG1 ${ }^{\mathrm{T}}$ was determined by the HPLC method (Mesbah et al., 1989), except that an Alltima C18 column $[250 \times 4.6 \mathrm{~mm}, 5 \mu \mathrm{m}$ particle size (Alltech)] and $8 \%(\mathrm{v} / \mathrm{v})$ methanol were used. The result reported is the mean of two determinations for each of two degradations of the DNA. The $\mathrm{G}+\mathrm{C}$ content of the genomic DNA of strain ASpG1 ${ }^{\mathrm{T}}$ was $58 \cdot 5 \pm 0 \cdot 2 \mathrm{~mol} \%$ (mean $\pm \mathrm{SD}, n=4)$.

Genomic DNA was isolated through phenol/chloroform extraction followed by ethanol precipitation (Ausubel et al., 1987). The $16 \mathrm{~S}$ rRNA gene of strain $A S p G 1^{T}$ was selectively 
amplified by PCR using primers designed by us: $5^{\prime}-$ AGAGTTTGATCCTGGCTCAG-3' (forward, Escherichia coli positions 8-27); 5'-TACGGCTACCTTGTTACGAC-3' (reverse, E. coli positions 1512-1493). PCR was performed with $30 \mathrm{pmol}$ of each primer in a total volume of $50 \mu \mathrm{l}$, using $1.2 \mathrm{U} P f u$ polymerase (Promega) in the provided buffer, $10 \mathrm{nmol}$ of each dNTP and $10 \%$ DMSO. The thermal cycling profile used was $5 \mathrm{~min}$ at $95^{\circ} \mathrm{C}$ (initial denaturation), followed by 10 cycles of $2 \mathrm{~min}$ at $95^{\circ} \mathrm{C}$ (denaturation), $45 \mathrm{~s}$ at $56^{\circ} \mathrm{C}$ (annealing) and $3 \mathrm{~min}$ at $73^{\circ} \mathrm{C}$ (extension), then 20 additional cycles with annealing at $50{ }^{\circ} \mathrm{C}$ (other parameters were the same as for the first 10 cycles). The final extension step was for $15 \mathrm{~min}$ at $73^{\circ} \mathrm{C}$. The amplified fragment was extracted from a $1.5 \%$ agarose gel using the Qiaquick extraction kit (Qiagen), then subcloned using the Zero Blunt TOPO PCR Cloning kit (Invitrogen). Three clones were sequenced in both directions using the dye terminator AmpliTaq FS cycle sequencing kit (Applied Biosystems), with both vector-specific primers (T3 and T7) and the following primers (designed by us), which were specific to internal regions of the $16 \mathrm{~S}$ rRNA gene: 5' -CGGAATTACTGGGCGTAAAG-3' (E. coli positions 555-574); 5'-GTGCTGCATGGCTGTCGTC-3' (E. coli positions 1047-1065); 5'-GGGTTGCGCTCGTTGCGGG-3' (E. coli positions 1113-1095); 5'-GCGCTCGCTTTACGCCCAAT-3' (E. coli positions 581-562). The 16S rRNA gene sequence of strain $A S p G 1^{\mathrm{T}}$ was aligned with those of 12 closely related sequences found in GenBank after a BLAST search (Altschul et al., 1990). The alignment was done using the PILEUP program from the Genetic Computer Group (GCG) package. Pairwise distances were computed with MEGA version 2.0 (Kumar et al., 2001) using the Jukes-Cantor model (Jukes \& Cantor, 1969). An unrooted phylogenetic tree was constructed with the same MEGA program using the neighbour-joining method (Saitou \& Nei, 1987).

A sequence covering $1467 \mathrm{nt}$ of the 16S rRNA gene of strain $\mathrm{ASpG}{ }^{\mathrm{T}}$ was obtained, corresponding to positions 28-1551 of the E. coli $16 \mathrm{~S}$ rDNA sequence. The G+C content of this sequence was $55.96 \mathrm{~mol} \%$. The sequence was compared with all sequences presently available in the GenBank database and appeared to be highly similar to sequences from the spirochaete group of organisms. A dendrogram showing the phylogenetic relationship of strain
$\mathrm{ASpG1} 1^{\mathrm{T}}$ to other spirochaetes, based on 1223 common nucleotide positions, was constructed (Fig. 2). Strain $\mathrm{ASpG1}^{\mathrm{T}}$ appears to belong to the alkaliphilic-halophilic cluster of spirochaetes, with similarity values ranging between 88.4 and $99.3 \%$ (distances based on $1223 \mathrm{nt}$ positions). The highest similarity was observed with S. alkalica Z-7491 $1^{\mathrm{T}}$. A pairwise alignment of the $16 \mathrm{~S} \mathrm{rDNA}$ sequence of strain $\mathrm{ASpG1}^{\mathrm{T}}$ with the complete available sequence of the $S$. alkalica $16 \mathrm{~S}$ rRNA gene showed $99 \cdot 2 \%$ identity (1446 nt) with $1457 \mathrm{nt}$ positions compared.

Since the phylogenetic analysis showed a high level of sequence similarity between strain $\mathrm{ASpG} 1^{\mathrm{T}}$ and $S$. alkalica Z-7491 ${ }^{\mathrm{T}}$, additional analyses were carried out to measure the DNA melting temperatures, genome sizes and DNADNA hybridization values for the two strains. Melting temperatures $\left(T_{\mathrm{m}}\right)$ of total genomic DNA from S. alkalica and strain $A S p G 1^{T}$ were determined by following the procedures described by De Ley et al. (1970) and Gillis et al. (1970). The $T_{\mathrm{m}}$ value for the genomic DNA of strain ASpG1 $1^{\mathrm{T}}$ was $68 \pm 2{ }^{\circ} \mathrm{C}$ (mean $\pm \mathrm{SD}, n=3$ ), whereas it was $74 \pm 2{ }^{\circ} \mathrm{C}($ mean $\pm \mathrm{SD}, n=3)$ for S. alkalica Z $-7491^{\mathrm{T}}$. The genome size of strain $\mathrm{ASpG1}^{\mathrm{T}}$ was $2.98 \times 10^{9} \mathrm{Da}$, as calculated using the equation described by Gillis et al. (1970) and the reported genome size of S. alkalica Z-7491 ${ }^{\mathrm{T}}$ (Zhilina et al., 1996). A comparison of the genome size of strain $A S p G 1^{T}$ with those of previously reported haloalkaliphilic spirochaetes is provided in Table 1 .

To determine the percentage homology of genomic DNA between S. alkalica Z-7491 ${ }^{\mathrm{T}}$ and strain AspG1 ${ }^{\mathrm{T}}$, DNA-DNA hybridization was performed followed by DNA reassociation kinetics as described by De Ley et al. (1970) and Johnson (1985). Genomic DNA from both of these microorganisms was sonicated using a Sonic Dismembrator 50 (Fisher Scientific) to generate DNA fragments of between 400 and $800 \mathrm{bp}$ in size. Residual RNA or single-stranded DNA was removed by using RNase I (Sigma) or S1 nuclease (US Biochemical) (Ausubel et al., 1987), respectively. The concentration and purity of the DNA were determined at $260 \mathrm{~nm}$ and a ratio of $260 / 280 \mathrm{~nm}$, respectively, by using a Shimadzu UV-160 spectrophotometer. Initial reassociation kinetics were determined by linear regression analysis. DNA-DNA hybridization established $48 \cdot 7 \%$ homology between the genomes of strain $\mathrm{ASpG}^{\mathrm{T}}$ and S. alkalica $\mathrm{Z}-7491^{\mathrm{T}}$ based on the reassociation kinetics and the

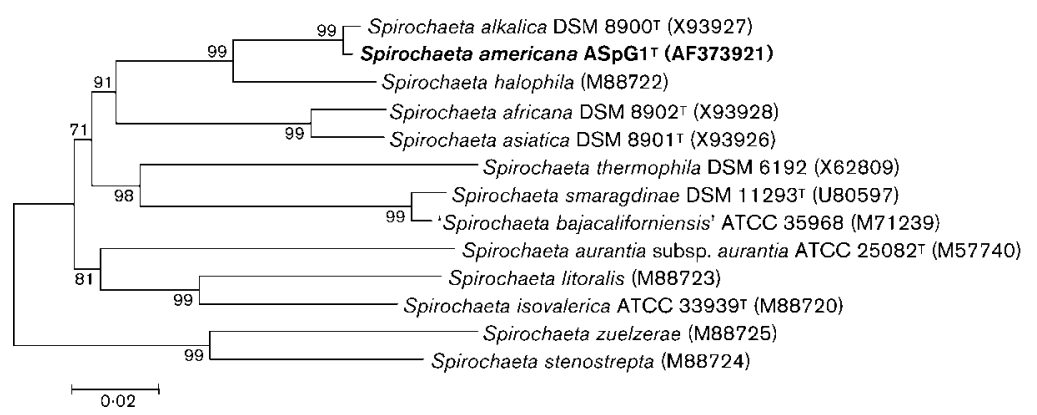

Fig. 2. Unrooted phylogenetic tree, constructed from 16S rRNA gene sequences, showing the position of strain $\mathrm{ASpG}_{1}{ }^{\top}$ within the spirochaetes. Sequence accession numbers are shown in parentheses; culture collection codes are given, if known. Bar, 2 substitutions per 100 nucleotides. 
Table 1. Comparison of morphological and physiological characteristics of strain $A S p G 1^{\top}$ with those of other members of the genus Spirochaeta

Species: 1, S. americana ASpG1 ${ }^{\mathrm{T}}$ (this study); 2, S. alkalica Z-7491 ${ }^{\mathrm{T}}$ (Zhilina et al., 1996); 3, S. africana Z-7492 ${ }^{\mathrm{T}}$ (Zhilina et al., 1996); 4, S. asiatica Z-7591 ${ }^{\mathrm{T}}$ (Zhilina et al., 1996); 5, S. halophila RS1 ${ }^{\mathrm{T}}$ (Greenberg \& Canale-Parola, 1976). ND, Not determined; +, substrate used/positive; -, substrate not used/negative; OA, obligate anaerobe; FA, facultative anaerobe. All strains utilized D-glucose, maltose, sucrose and starch as substrates. All strains produced acetate and ethanol from glucose.

\begin{tabular}{|c|c|c|c|c|c|}
\hline Characteristic & 1 & 2 & 3 & 4 & 5 \\
\hline Optimum (range) $\mathrm{pH}$ & $9 \cdot 5(8 \cdot 0-10 \cdot 5)$ & $8 \cdot 7-9 \cdot 6(8 \cdot 4-10 \cdot 7)$ & $8 \cdot 8-9 \cdot 75(8 \cdot 1-10 \cdot 7)$ & $8 \cdot 4-9 \cdot 4(7 \cdot 9-9 \cdot 7)$ & $7 \cdot 5$ \\
\hline Optimum (range) temperature $\left({ }^{\circ} \mathrm{C}\right)$ & $37(10-45)$ & $33-37(15-44)$ & $30-37(15-47)$ & $33-37(20-43)$ & $35-40$ \\
\hline \multicolumn{6}{|l|}{ Substrate: } \\
\hline Fructose & + & + & + & - & + \\
\hline \multicolumn{6}{|l|}{ Product of glucose fermentation: } \\
\hline $\mathrm{H}_{2}$ & + & + & + & - & + \\
\hline Formate & + & $\mathrm{ND}$ & ND & $\mathrm{ND}$ & - \\
\hline Lactate & - & + & + & + & + \\
\hline Relationship to $\mathrm{O}_{2}$ & $\mathrm{OA}$ & $\mathrm{FA}$ & FA & $\mathrm{OA}$ & FA \\
\hline
\end{tabular}

equation described by Gillis et al. (1970). All statistical analyses were performed using Microsoft Excel.

Strain ASpG1 ${ }^{\mathrm{T}}$ was isolated from Mono Lake, an ancient ( $~ 750000$ years old), continental, athalassic, sulfurous, hypersaline $\left(\sim 80 \mathrm{~g} \mathrm{NaCl}^{-1}\right)$, alkaline ( $\left.\mathrm{pH} 9 \cdot 4-10 \cdot 5\right)$ soda lake in California. Mono Lake is a closed basin with high evaporation rates that is in close proximity to active volcanoes (Tierney, 1997). Dominant ions of Mono Lake water ( $\mathrm{pH} \mathrm{9 \cdot 7)}$ are sodium $(1400 \mathrm{mM})$, carbonate $(400 \mathrm{mM})$ and sulfate $(130 \mathrm{mM})$ (Oremland \& Miller, 1993). The salinity of Mono Lake varies with the water level and has ranged from $\sim 50$ to $\sim 100 \mathrm{~g}$ salt $^{-1}$ (when Mono Lake was at its lowest level, in 1982).

The volcanic island Paoha, with a hot $\left(\sim 90^{\circ} \mathrm{C}\right)$ alkaline spring, emerged only 350 years ago in the middle of Mono Lake. In the winter months, along the south shoreline, metastable minerals such as gaylussite $\left[\mathrm{CaNa}_{2}\left(\mathrm{CO}_{3}\right)_{2} \cdot 5\left(\mathrm{H}_{2} \mathrm{O}\right)\right]$ and ikaite $\left(\mathrm{CaCO}_{3} \cdot 6 \mathrm{H}_{2} \mathrm{O}\right)$ precipitate abundantly (Bischoff et al., 1991, 1993; Council \& Bennett, 1993). In warmer months, these minerals transform into tufa (anhydrous $\mathrm{CaCO}_{3}$ ), and tufa columns grow where calcium-rich spring water mixes with alkaline lake water. The microbial community of Mono Lake exhibits a complete cycle of trophic chains: the primary producers are phototrophs, such as cyanobacteria, diatoms and other algae, and the primary micro-organisms responsible for the destruction of organic matter under anaerobic conditions include species of Spirochaeta (strain $\mathrm{ASpG}^{\mathrm{T}}$ ) and Tindallia (novel strain APO), some cellulolytic bacteria and secondary anaerobes, such as Desulfonatronum sp. (novel sulfate-reducer strain MLF1), using the end products of primary anaerobes.
On the basis of its phenotypic characteristics (e.g. cell morphology, Gram-negative cell wall and fermentation of sugars), strain $\mathrm{ASpG} 1^{\mathrm{T}}$ was identified as a member of the genus Spirochaeta. Among the alkaliphilic spirochaete species, strain $\mathrm{ASpG} 1^{\mathrm{T}}$ is the only haloalkaliphile capable of growth in a medium containing $12 \% \mathrm{NaCl}$ and with a $\mathrm{pH}$ of 9.5. Strain $A S p G 1^{T}$ was also shown to be a member of the genus Spirochaeta by a molecular phylogenetic analysis. The significant differences between the morphological and physiological characteristics of strain $\mathrm{ASpG} 1^{\mathrm{T}}$ and its closest phylogenetic relatives of the genus Spirochaeta are shown in Table 1. Strain ASpG1 ${ }^{\mathrm{T}}$ is notably different from its nearest phylogenetic neighbour, S. alkalica Z-7491 ${ }^{\mathrm{T}}$, in both its cell morphology and size; both strains also exhibit differences in important physiological and metabolic characteristics, such as the ability to use D-mannitol, production of lactate from glucose fermentation and their relationship to oxygen (strain $\mathrm{ASpG1}^{\mathrm{T}}$ is an obligate anaerobe, whereas S. alkalica $\mathrm{Z}-7491^{\mathrm{T}}$ is a facultative anaerobe). In addition, strain $\mathrm{ASpG1} 1^{\mathrm{T}}$ does not exhibit visible pigmentation (its biomass is white), but the biomass of $S$. alkalica cells is orange. Furthermore, cells of strain $A S p G 1^{\mathrm{T}}$ are regular-shaped spirals, but $S$. alkalica $\mathrm{Z}-7491^{\mathrm{T}}$ cells are irregular-shaped coils. Fatty acid analysis demonstrates the absence of branched-chain fatty acids in strain $\mathrm{ASpG1}^{\mathrm{T}}$, as was also observed for S. alkalica, S. africana, S. asiatica, S. halophila and $S$. litoralis. DNA-DNA hybridization of genomic DNA between strain $\mathrm{ASpG1} 1^{\mathrm{T}}$ and $S$. alkalica $\mathrm{Z}-7491^{\mathrm{T}}$ exhibited $48.7 \%$ homology. The $T_{\mathrm{m}}$ value for the genomic DNA of S. alkalica Z-7491 ${ }^{\mathrm{T}}$ was more than $5{ }^{\circ} \mathrm{C}$ higher than the $T_{\mathrm{m}}$ value for the genomic DNA of strain ASpG1 $1^{\mathrm{T}}$. Finally, the genome size of strain $\mathrm{ASpG1} 1^{\mathrm{T}}$ has been determined to be higher than that of $S$. alkalica $Z-7491^{\mathrm{T}}$, and the $\mathrm{G}+\mathrm{C}$ 
content of strain $A S p G 1^{\mathrm{T}}$ is $1.4 \mathrm{~mol} \%$ higher than that of S. alkalica $\mathrm{Z}-7491^{\mathrm{T}}$.

A comparison of the phenotypic and genotypic data for strain ASpG1 ${ }^{\mathrm{T}}$ with those of S. alkalica $\mathrm{Z}-7491^{\mathrm{T}}$ indicates that there are sufficient differences between the two strains for strain $\mathrm{ASpG} 1^{\mathrm{T}}$ to be considered a separate species of the genus Spirochaeta. Based upon the taxonomic criteria set forth by Wayne et al. (1987), the DNA reassociation value of $48 \cdot 7 \%$ between strain $\mathrm{ASpG} 1^{\mathrm{T}}$ and S. alkalica $\mathrm{Z}-7491^{\mathrm{T}}$ supports this assertion. Two of the alkaliphilic species of the genus Spirochaeta were named after the continent from which they were collected (S. africana $\mathrm{Z}-7692^{\mathrm{T}}$ from soda Lake Magadi in Central Africa and S. asiatica Z-7591 ${ }^{\mathrm{T}}$ from Lake Khatyn of Central Asia; Zhilina et al., 1996). In accordance with this convention, the name Spirochaeta americana is proposed for strain $\mathrm{ASpG} 1^{\mathrm{T}}$, which represents the first haloalkaliphilic spirochaete isolated from the American continents.

\section{Description of Spirochaeta americana sp. nov.}

Spirochaeta americana (a.mer.i.can'a. N.L. fem. adj. americana of American continent, isolated from soda Mono Lake, California, USA).

Cells are motile and helix-shaped. Flagellum present in periplasmic space. Gram-negative. Cells have regular, unstable primary coils. Sphaeroplasts are formed at the end of the growth phase. Haloalkaliphile that cannot grow at $\mathrm{pH} 7 \cdot 0$. Growth is dependent upon the presence of carbonate and sodium ions in the medium. No growth occurs below $2 \%(\mathrm{w} / \mathrm{v}) \mathrm{NaCl}$ or above $12 \%(\mathrm{w} / \mathrm{v}) \mathrm{NaCl}$. Mesophilic. Cells can be stored frozen in a liquid medium. Strictly anaerobic, catalase-negative chemoheterotroph with fermentative type of metabolism. Preferred substrates are D-glucose, fructose, maltose, sucrose, starch and D-mannitol. Requires vitamins and yeast extract for growth. Primary end product of glucose fermentation is $\mathrm{H}_{2}$; the minor end products in the stationary phase of growth are acetate, formate, ethanol and $\mathrm{CO}_{2}$. Resistant to kanamycin and rifampicin, but sensitive to gentamicin, tetracycline and chloramphenicol. Other characteristics of the species can be found in Table 1 .

The type strain of Spirochaeta americana is $\mathrm{ASpG}^{\mathrm{T}}$ $\left(=\mathrm{ATCC} \quad \mathrm{BAA}-392^{\mathrm{T}}=\mathrm{DSM} \quad 14872^{\mathrm{T}}\right)$. The $T_{\mathrm{m}}$ of its genomic DNA is $68 \pm 2{ }^{\circ} \mathrm{C}$. Isolated from mud sediments of the alkaline, hypersaline, meromictic, soda Mono Lake in northern California, USA.

\section{Acknowledgements}

We thank Dr V. Kevbrin and Professor J. Wiegel (University of Georgia, Athens, GA, USA) for their help with measuring end products, and Dr Robert Angus and Dr Steve Watts (University of Alabama at Birmingham, AL, USA) for their assistance with statistical analysis and laboratory facilities. We also thank Dave Cleland (ATCC) for growing biomass for analysis of fatty acids and Greg Jerman of NASA/MSFC for scanning electron microscopy. We gratefully acknowledge the NASA JSC Astrobiology Institute for Biomarkers in Astromaterials for funding this research.

\section{References}

Aksenova, H. Y., Rainey, F. A., Janssen, P. H., Zavarzin, G. A. \& Morgan, H. W. (1992). Spirochaeta thermophila sp. nov., an obligately anaerobic, polysaccharolytic, extremely thermophilic bacterium. Int J Syst Bacteriol 42, 175-177.

Altschul, S. F., Gish, W., Miller, W., Myers, E. W. \& Lipman, D. J. (1990). Basic local alignment search tool. J Mol Biol 215, 403-410.

Ausubel, F. M., Brent, R., Kingston, R. E., Moore, D. D., Seidman, J. G., Smith, J. A. \& Struhl, K. (1987). Current Protocols in Molecular Biology, pp. 2.10-2.11. New York: Wiley.

Barth, A. L., Stricker, J. A. \& Margulis, L. (1991). Search for eukaryotic motility proteins in spirochetes: immunological detection of a tektin-like protein in Spirochaeta halophila. Biosystems 24, 313-319.

Bermudes, D., Fracek, S. P., Jr, Laursen, R. A., Margulis, L., Obar, R. \& Tzertzinis, G. (1987). Tubulinlike protein from Spirochaeta bajacaliforniensis. Ann N Y Acad Sci 503, 515-527.

Bischoff, J. L., Herbst, D. B. \& Rosenbauer, R. J. (1991). Gaylussite formation at Mono Lake, California, USA. Geochim Cosmochim Acta 55, 1743-1747.

Bischoff, J. L., Stine, S., Rosenbauer, R. J., Fitzpatrick, J. A. \& Stafford, T. W., Jr (1993). Ikaite precipitation by mixing of shoreline springs and lake water, Mono Lake, California, USA. Geochim Cosmochim Acta 57, 3855-3856.

Breznak, J. A. \& Canale-Parola, E. (1975). Morphology and physiology of Spirochaeta aurantia strains isolated from aquatic habitats. Arch Microbiol 105, 1-12.

Canale-Parola, E. (1977). Physiology and evolution of Spirochetes. Bacteriol Rev 41, 181-204.

Canale-Parola, E. (1980). Revival of the names Spirochaeta litoralis, Spirochaeta zuelzerae, and Spirochaeta aurantia. Int J Syst Bacteriol 30, 594.

Canale-Parola, E. (1984). Genus I. Spirochaeta Ehrenberg 1835, $313^{\mathrm{AL}}$. In Bergey's Manual of Systematic Bacteriology, vol. 1, pp. 39-46. Edited by N. R. Krieg \& J. G. Holt. Baltimore: Williams \& Wilkins.

Canale-Parola, E. (1992). Free-living saccharolytic spirochetes: the genus Spirochaeta. In The Prokaryotes, 2nd edn, pp. 3524-3536. Edited by A. Balows, H. G. Trüper, M. Dworkin, W. Harder \& K.-H. Schleifer. New York: Springer-Verlag.

Council, T. C. \& Bennett, P. C. (1993). Geochemistry of ikaite formation at Mono Lake, California: implications for the origin of tufa mounds. Geology 21, 971-974.

De Ley, J., Cattoir, H. \& Reynaerts, A. (1970). The quantitative measurement of DNA hybridization from renaturation rates. Biochemistry 12, 133-142.

Fracek, S. P., Jr \& Stolz, J. F. (1985). Spirochaeta bajacaliforniensis sp. n. from a microbial mat community at Laguna Figueroa, Baja California Norte, Mexico. Arch Microbiol 142, 317-325.

Gerhardt, P., Murray, R. G. E., Costilow, R. N., Nester, E. W., Wood, W. A., Krieg, N. R. \& Phillips, G. B. (editors) (1981). Manual of Methods for General Bacteriology. Washington, DC: American Society for Microbiology.

Gillis, M., De Ley, J. \& De Cleene, M. (1970). The determination of molecular weight of bacterial genome DNA from renaturation rates. Eur J Biochem 12, 143-153. 
Greenberg, E. P. \& Canale-Parola, E. (1976). Spirochaeta halophila sp. n., a facultative anaerobe from a high-salinity pond. Arch Microbiol 110, 185-194.

Harwood, C. S., Jannasch, H. W. \& Canale-Parola, E. (1982). Anaerobic Spirochete from a deep-sea hydrothermal vent. Appl Environ Microbiol 44, 234-237.

Harwood, C. S. \& Canale-Parola, E. (1983). Spirochaeta isovalerica sp. nov., a marine anaerobe that forms branched-chain fatty acids as fermentation products. Int J Syst Bacteriol 33, 573-579.

Hespell, R. B. \& Canale-Parola, E. (1970). Spirochaeta litoralis sp. n., a strictly anaerobic marine spirochete. Arch Microbiol 74, 1-18.

Hungate, R. E. (1969). A roll tube method for cultivation of strict anaerobes. In Methods in Microbiology, vol. 3B, pp. 117-132. Edited by J. R. Norris \& D. W. Ribbons. New York. Academic Press.

Johnson, J. L. (1985). DNA reassociation and RNA hybridization of bacterial nucleic acids. Methods Microbiol 18, 33-74.

Jukes, T. H. \& Cantor, C. R. (1969). Evolution of protein molecules. In Mammalian Protein Metabolism, pp. 21-132. Edited by H. N. Munro. New York: Academic Press.

Kumar, S., Tamura, K., Jakobsen, I. B. \& Nei, M. (2001). MEGA2: molecular evolutionary genetics analysis software. Bioinformatics 17, 1244-1245.

Magot, M., Fardeau, M.-L., Arnauld, O., Lanau, C., Olivier, B., Thomas, P. \& Patel, B. K. C. (1997). Spirochaeta smaragdinae sp. nov., a new mesophilic strictly anaerobic spirochete from an oil field. FEMS Micobiol Lett 155, 185-191.

Mesbah, M., Premachandran, U. \& Whitman, W. B. (1989). Precise measurement of the $\mathrm{G}+\mathrm{C}$ content of deoxyribonucleic acid by highperformance liquid chromatography. Int J Syst Bacteriol 39, 159-167.

Munson, D., Obar, R., Tzertzinis, G. \& Margulis, L. (1993). The 'tubulin-like' S1 protein of Spirochaeta is a member of the hsp65 stress protein family. Biosystems 31, 161-167.

Oremland, R. S. \& Miller, L. G. (1993). Biochemistry of natural gases in three alkaline, permanently stratified (meromictic) lakes. In The
Future of Energy Gases, pp. 439-452. Edited by D. Howell. USGS Prof. Paper 1570.

Paster, B. J., Dewhirst, F. E., Weisburg, W. G. \& 7 other authors (1991). Phylogenetic analysis of the spirochetes. J Bacteriol 19, 6101-6109.

Patel, B. K. C., Morgan, H. W. \& Daniel, R. M. (1985). Thermophilic anaerobic spirochetes in New Zealand hot springs. FEMS Microbiol Lett 26, 101-106.

Pohlschroeder, M., Leschine, S. B. \& Canale-Parola, E. (1994). Spirochaeta caldaria sp. nov., a thermophilic bacterium that enhances cellulose degradation by Clostridium thermocellum. Arch Microbiol $161,17-24$.

Saitou, N. \& Nei, M. (1987). The neighbor-joining method: a new method for reconstructing phylogenetic trees. Mol Biol Evol 4, 406-425.

Teal, T. H., Chapman, M., Guillemette, T. \& Margulis, L. (1996). Freeliving spirochetes from Cape Cod microbial mats detected by electron microscopy. Microbiologia 12, 571-584.

Tierney, T. (1997). Geology of the Mono Basin, pp. 1-73. Mono Lake Committee, Lee Vining, California: Kutsavi Press.

Wayne, L. G., Brenner, D. J., Colwell, R. R. \& 9 other authors (1987). International Committee on Systematic Bacteriology. Report of the ad hoc committee on reconciliation of approaches to bacterial systematics. Int J Syst Bacteriol 37, 463-464.

Whitman, W. B., Ankwanda, E. \& Wolfe, R. S. (1982). Nutrition and carbon metabolism of Methanococcus voltae. J Bacteriol 149, 852-863.

Wolin, E. A., Wolin, M. J. \& Wolfe, R. S. (1963). Formation of methane by bacterial extracts. J Biol Chem 238, 2882-2886.

Zhilina, T. N., Zavarzin, G. A., Rainey, F., Kevbrin, V. V., Kostrikina, N. A. \& Lysenko, A. M. (1996). Spirochaeta alkalica sp. nov., Spirochaeta africana sp. nov., and Spirochaeta asiatica sp. nov., alkaliphilic anaerobes from the continental soda lakes in Central Asia and the East African Rift. Int J Syst Bacteriol 46, 305-312. 